\title{
Effects of crowding on blood constituents and flesh quality variables in Atlantic salmon (Salmo salar L.)
}

\author{
Efecto del confinamiento sobre las variables sanguíneas y \\ calidad de carne de Salmón Atlántico (Salmo salar L.) \\ MC Gatica ${ }^{\text {a }}$, GE Monti ${ }^{\mathrm{b}}$, TG Knowles ${ }^{\mathrm{c}}$, CB Gallo \\ anstituto de Ciencia Animal y Tecnología de Carnes, Facultad de Ciencias Veterinarias, \\ Universidad Austral de Chile, Campus Isla Teja, Valdivia, Chile. \\ bInstituto de Medicina Preventiva Veterinaria, Facultad de Ciencias Veterinarias, \\ Universidad Austral de Chile, Campus Isla Teja, Valdivia, Chile. \\ ${ }^{\mathrm{c} S c h o o l}$ of Clinical Veterinary Science, University of Bristol, Langford, Bristol, UK.
}

\begin{abstract}
RESUMEN
Se compararon en los días 0,1 , 4, 7 y 10 post mortem, en términos de variables de la calidad de la carne y constituyentes sanguíneos, los efectos de la anestesia (como tratamiento del control) y el confinamiento controlado con disminución del nivel de oxígeno en salmones tamaño cosecha (Salmo salar). Los peces fueron mantenidos en triplicado en estanques y muestreados después de anestesiar con AQUI-S ${ }^{\circledR}$ y después de confinar por un período de una hora. Dieciocho peces de cada tratamiento fueron insensibilizados mediante un golpe en la cabeza, se les extrajo sangre mediante la punción de la vena caudal para luego ser sangrados mediante el corte de branquias y posteriormente procesados para obtener los filetes. Todas las variables sanguíneas a excepción del cortisol fueron significativamente más altas $(\mathrm{P}<0,05)$ en los peces confinados comparados con los peces anestesiados. El $\mathrm{pH}$ muscular inicial fue más bajo en los pescados confinados únicamente en los días 0,1 y 4 post mortem. El color muscular obtuvo una puntuación significativamente más baja $(\mathrm{P}<0,05)$ en los peces confinados que en aquellos anestesiados en los días 0 y 1 post mortem. La pérdida del peso fue mayor $(\mathrm{P}<0,05)$ en los peces confinados, aumentando en ambos tratamientos en los siguientes días post mortem. La concentración de astaxantina muscular no mostró ninguna diferencia estadística entre los tratamientos ni en los días post mortem. Se puede concluir que el confinamiento y el bajo nivel de oxígeno tienen un efecto negativo en las variables sanguíneas y en parámetros de calidad de carne, disminuyendo la puntuación de color, bajando el pH muscular inicial y aumentando la pérdida del peso de los filetes.
\end{abstract}

Key words: stress, quality, blood, $\mathrm{pH}$, cortisol.

Palabras clave: stress, calidad, sangre, $\mathrm{pH}$, cortisol.

\section{INTRODUCTION}

Animal welfare has become a subject of great importance in farm animals and is also an important topic to consider in farmed fish (Kestin et al 1995, Håstein 2004). Intensively produced fish are exposed to management practices such as handling, transportation or confinement which elicit stress responses. There is an extensive literature that has examined the response of fish to typical stressors in aquaculture practices (Barton 2002, Acerete et al 2004). 'Stressors' can be multiple and of diverse origin: deficient feeding, high stocking densities, low water oxygen, inappropriate water conditions (physical-chemical), $\mathrm{pH}$, inappropriate temperature, high carbon dioxide levels, ammonium, nitrites, sulphydric acid, organic matter in the water, salinity, photo and/or thermo period, vibrations and noises, injuries from handling (harvests, transport) (Rottmann et al 1992, Ruiz

Accepted: 06.08.2010.

* cristinagatica@gmail.com et al 2003), high metal concentrations in water, as well as pollution (Iwama et al 2004). Kestin (1994), identified handling and confinement as the major "stressing" agents in commercial salmon aquaculture.

Increasing stocking density is one method of increasing productivity at the growing farm, however, high densities have been shown to produce aggressive behaviour, reduce feed conversion and growth rate, decrease water quality and increase the presence of physical injuries (Wall 2001).

High stocking densities were identified as one of the main causes of problems related to flesh quality as well as animal welfare (Wall 2001). High stocking densities are often associated with lowered water quality (excess ammonium and low oxygen tension). The increased proximity between fish contributes to the dissemination of disease, an increase in stress and a consequent reduction in the immune response (Kestin 1994). Bell et al (2002) did not find a correlation between high stocking densities and various measures of animal welfare until a break point of 20 to $24 \mathrm{~kg} / \mathrm{m}^{3}$, however, densities above this point were thought to jeopardize the welfare of the fish. 
Harvesting is an inevitable part of farmed fish production and places fish in an acute stress situation by reducing surrounding water volume and causing increased activity as fish attempt to escape (Thomas et al 1999). Further live transport in wellboats and high stocking densities in the resting cages before slaughtering are all stressful procedures (Skjervold et al 2001, Foucat et al 2004). The harvesting is under-represented in investigations into fish welfare, probably due to the endpoint (for the biologist) being the death of the fish (Erikson et al 1997', Thomas et al 1999, Skjervold et al 2001).

In Chile, live transportation of harvest size salmon to slaughter is common and carried out mainly in wellboats. The fish are loaded by means of pumps into the wellboat's chambers, where they are kept during the whole journey at high stocking densities (approximately $120 \mathrm{~kg} / \mathrm{m}^{3}$ ). Once the wellboat arrives at the processing plant's pier, unloading is either into the resting cages, where fish are kept at stocking densities between 25 and $30 \mathrm{~kg} / \mathrm{m}^{3}$, usually for a period of up to 24 hours, or directly to the processing plant to slaughter.

Disturbance during harvest and antemortem handling can be detected through physiological changes that can be used as indicators of the degree of stress experienced by the fish (Barton 2000). Fish respond in different ways to maintain homeostasis during stress and many physiological changes are involved in the stress response, including changes in osmolality, hormone release, and energetic metabolism (Barton and Iwama 1991, Wendelaar Bonga 1997).

Of great commercial importance is the influence that these changes have on various characteristics of flesh quality: firmness (Skjervold et al 2001), onset and duration of rigor mortis, muscle $\mathrm{pH}$, water holding capacity, texture, gaping and shelf life (Huss 1995, Thomas et al 1999, Skjervold et al 2001, Roth et al 2002, Foucat et al 2004, Jittinandana et al 2005). From a commercial, as well as from an animal welfare point of view, it is important to understand the nature of the physiological and metabolic changes in order to implement appropriate measures to reduce any deleterious effects (Kestin 1994, Pottinger 2001).

The aim of the present study was to evaluate the effect of crowding and low oxygen on blood levels of glucose, lactate, cortisol, sodium, chlorides and osmolality, and on flesh quality parameters of weight loss, asthaxantin content, colour and muscle $\mathrm{pH}$ in harvest size salmon (Salmo salar).

\section{MATERIAL AND METHODS}

\section{EXPERIMENTAL DESIGN}

Thirty six fish from a total of 75.4 , to $5 \mathrm{~kg}$ harvest size Atlantic salmon, that had been brought from cages to tanks and allowed to acclimatise for a period of 86 days before the trial, were used for the experiment. The fish were held in three $3000 \mathrm{~L}$. tanks, each holding 25 fish (aprox. $33 \mathrm{~kg} / \mathrm{m}^{3}$ ) at the biggining of the study. The tanks had an open flux of water with a total rechange of the water in 1 hour. The three tanks were considered as replicates. On the first day of the experiment, $30 \mathrm{mg} / \mathrm{L}$ of AQUI-S $®$ were used as an anaesthetic in all three tanks, dissolved directly into the water and left to act for a period of 30 minutes at the time that the flux of water was closed; then 6 fish at random were sampled individually from each tank by means of a ketch (Anaesthetized fish, $\mathrm{n}=18$ ). Each fish was stunned by a blow to the head, and a blood sample was obtained with a syringe from the posterior aorta. The blood was divided in two tubes, one with $\mathrm{NaF}$, to obtain plasma by means of centrifugation for glucose and lactate concentrate determination, and another without anticoagulant, to obtain serum for cortisol, osmolality, $\mathrm{Na}$ and $\mathrm{Cl}$ concentrate determination. Both plasma and serum were frozen $\left(-20^{\circ} \mathrm{C}\right)$ for later analysis. After blood sampling, the fish were killed by gill cut, hung by the peduncle and left to bleed out of the water for a period of one hour. After bleeding each fish was filleted and the Norwegian Quality Cut (NQC) from the left and right fillets were used to determine quality characteristics. Once the 18 anaesthetized fish were blood sampled from the three tanks, the flux of water was restored in each of them and the anaesthetic was eliminated.

The next day, the remaining fish were crowded, by means of a mesh inside the tanks and the escape of water, to a maximum density of $200 \mathrm{~kg} / \mathrm{m}^{3}$ over the period of one hour. Fifty per cent of the water was released from the tanks, and oxygen saturation level reduced from an average of $90 \%$ to $23 \%$. Fish from the 3 tanks (replicates) were crowded at 1 hour intervals to allow enough time to sample each tank before starting the next one. After one hour of crowding, six fish from each tank were taken individually out of the water in the same way the anaesthetized fish were sampled on day one (Crowded fish, $\mathrm{n}=18$ ). Then the holding mesh was removed and the water level in the tank returned to its original level.

\section{BLOOD VARIABLE ANALYSIS}

Glucose concentration was determined spectrophotometrically using the GOD-PAP method without deproteinization. The lactate concentration was also determined spectrophotometrically by means of an enzymatic-colorimetric method. Serum sodium concentration was determined with a Perkin-Elmer 238 atomic absorption spectrophotometer. Both urea and chlorides were determined colorimetrically using the GLDH enzymatic method and the tripyriditiazine (TPTZ) method respectively. Glucose, lactate, urea and chlorides were determined in an autoanalyzer (Cobas Mira Plus spectrophotometer $\left(\right.$ Roche $\left.^{\circledR}\right)$ ) by means of the colorimetric technique. Urea Nitrogen was determined in order to calculate osmolality using the formula: 


$$
\text { UreaNitrogen }=\frac{\text { urea }}{2.14} .
$$

Serum osmolality was then obtained using the formula:

(2)

$$
\text { mosmol / } k g=1.86[N a]+\left(\frac{G l u \cos e}{18}\right)+\left(\frac{\text { UreaN }}{2.8}\right)
$$

(Holmes 1962)

Cortisol concentration was determined by a RIA technique (Radio Immune Assay). The samples were measured on a radioimmunoassay using marked cortisol with iodine 125 and this marked hormone is made to compete with cold hormone, which is in the samples. As the antibody is attached to the tube, this test is called "coat-to-count". The antibody is highly specific for cortisol and has very low reaction crossed with other steroids such as cortisone and corticosterone. At FISENLAB laboratory all RIAs have been validated for use in animals.

\section{MUSCLE PH, COLOUR, ASTHAXANTIN CONTENT AND PERCENTAGE WEIGHT LOSS}

Muscle $\mathrm{pH}$ and colour scores were determined at 0 (1 hour post-mortem), 1, 4, 7 and 10 days post-mortem. Muscle $\mathrm{pH}$ was measured by directly inserting a $\mathrm{pH}$ probe (Checker 200) in the left NQC fillet of each fish; probe insertion was always performed at the same position and by the same person. At the same time, visual colour scores were obtained using the DSM SalmoFan (DSM Nutritional Products, Chile), which uses a scale ranging from 21 (light red) to 34 (dark red), under standardised illumination in a Salmon Colour Box and by the same person every time. Asthaxantin content was determined by HPLC on days 1, 4, 7 and 10 postmortem, also in the left NQC fillet. Between measurements the fillets were kept refrigerated $\left(0-4{ }^{\circ} \mathrm{C}\right)$ in individually labelled plastic bags. The right $\mathrm{NQC}$ fillets were weighed and also kept individually labelled in refrigeration $\left(0-4{ }^{\circ} \mathrm{C}\right)$; any liquid exudate present in the bag was wiped off before each weighing. Weight loss was determined as the difference between day 1 and days 4, 7,10, and then calculated as a percentage of the initial weight on day 1 . All flesh quality analysis were performed at TraceLab Analytical Services, Puerto Montt, Chile.

\section{STATISTICAL ANALYSIS}

The normality of the distribution of the blood variables was determined by visual inspection of a histogram and by means of the Shapiro-Wilks Normality Test. A two sample t-test was used to test variables with a normal distribution and the Wilcoxon Rank Sum Test for those not normally distributed. Flesh quality data were repeated measures and were analysed with a model that allowed a varying intercept (Singer and Willett 2003), expressed as:

$\mathrm{Y}_{i j}=\mathrm{b}_{0 \mathrm{ij}}+\beta_{1}$ Days post mortem $0_{\mathrm{j}}+\ldots \beta_{3}$ Days post mortem $10_{j}+\beta_{4}$ Treatment $_{j}$ $\mathrm{b}_{0 \mathrm{ij}}=\pi_{0 \mathrm{i}}+\mu_{0 \mathrm{j}}+\varepsilon_{0 \mathrm{ij}}$

Where $\mathrm{i}=$ days postmortem and $\mathrm{j}=$ individual

This model assumes that $\mu_{0 \mathrm{j}}$ takes a particular variance structure (simple, compound symmetry first-order autoregressive and unstructured (more details in the next paragraph) for the repeated measures within-individuals and the error term $\varepsilon_{0 \mathrm{ij}}$ is a Gaussian random variable that are uncorrelated and have expectations 0 and and variances $\Omega_{\varepsilon}\left(\mathrm{N}\left(0, \Omega_{\varepsilon}\right)\right.$ (Singer 1998).

With typical repeated measures, as here, two measurements that are taken at adjacent time are more correlated than those measurements taken several time points apart (Little et al 1996). Therefore, it is important to account for these correlations in estimating the effects of time and of treatment.

Several error structures were evaluated including simple (no correlation), compound symmetry, first-order autoregressive and unstructured (estimating a correlation for each separate correlation). The different correlation structures were evaluated using Akaike's Information Criterion (AIC). AIC can be used to compare models with the same fixed effects but that differ in the variance structure (Little et al 1996). We found the first-order autoregressive $(\mathrm{AR}(1))$ correlation structure to provide the best fit to these data. For the first-order autoregressive model, the correlations decrease exponentially with the distance between measurements. Therefore, we illustrate below a correlation sub-matrix for the $i$ th individual:

$$
\left[\begin{array}{cccc}
1 & \rho & \rho 2 & \rho 3 \\
\rho & 1 & \rho & \rho 2 \\
\rho 2 & \rho & 1 & \rho \\
\rho 3 & \rho 2 & \rho & 1
\end{array}\right]
$$

Analysis were performed in SAS V.9.1 and statistical significance was defined at $\mathrm{P}<0.05$.

\section{RESULTS}

The results from the analysis of blood constituents for each group are shown in table 1 . All of the blood variables analyzed, (glucose, lactate, $\mathrm{Na}, \mathrm{Cl}$ and osmolarity) with the exception of cortisol, increased $(\mathrm{P}<0.05)$ in the salmon which were crowded.

The results from the flesh quality measurements are shown in table 2 . Flesh colour was significantly lower $(\mathrm{P}<0.05)$ in crowded salmon, both at death and on day 1 , post mortem. 
Table 1. Anaesthetized and crowded salmon's blood variables. Mean and SD.

Variables sanguíneas para salmón anestesiado y en confinamiento. Promedio y DS.

\begin{tabular}{|c|c|c|c|c|c|c|}
\hline Treatment & $\begin{array}{c}\text { Glucose } \\
\mathrm{mmol} / \mathrm{L}(\mathrm{SD})\end{array}$ & $\begin{array}{c}\text { Lactate } \\
\mathrm{mmol} / \mathrm{L} \\
(\mathrm{SD})\end{array}$ & $\begin{array}{c}\text { Cortisol } \\
\mathrm{ng} / \mathrm{ml} \text { (SD) }\end{array}$ & $\begin{array}{c}\mathrm{Na} \\
\mathrm{mmol} / \mathrm{L}(\mathrm{SD})\end{array}$ & $\begin{array}{c}\mathrm{Cl} \\
\mathrm{mmol} / \mathrm{L} \\
(\mathrm{SD})\end{array}$ & $\begin{array}{l}\text { Osmolality } \\
\mathrm{mosm} / \mathrm{kg} \\
\text { (SD) }\end{array}$ \\
\hline Anesthetised & $4.26 *(1.1)$ & $3.40 *(3.2)$ & $242.79(78.9)$ & $149.82 *(22.7)$ & $126.37 *(31.8)$ & $263.77 *(77.4)$ \\
\hline Crowded & $7.52(1.9)$ & $14.0(4.3)$ & $284.53(60.6)$ & $161.33(10.8)$ & $139.35(3.0)$ & $300.87(20.1)$ \\
\hline
\end{tabular}

* For a variable, it indicates statistical differences between treatment groups $(\mathrm{P}<0.05)$.

Table 2. Mean and SD of anaesthetized (Anaest) and crowded salmon's muscle colour, muscle pH, asthaxantine content and weight loss percentage on days $0,1,4,7$ and 10 post-mortem.

Promedio y DS para salmón anestesiado (Anaest) y en confinamiento para color muscular, pH muscular, contenido de astaxantina y porcentaje de pérdida de peso en los días $0,1,4,7$ y 10 post-mortem.

\begin{tabular}{|c|c|c|c|c|c|c|c|c|}
\hline \multirow{3}{*}{$\begin{array}{l}\text { Treatment } \\
\text { Day P-M } \\
0\end{array}$} & \multicolumn{2}{|c|}{$\begin{array}{c}\text { Colour } \\
\text { Salmofan (SD) }\end{array}$} & \multicolumn{2}{|c|}{$\begin{array}{l}\text { Muscle pH } \\
\mathrm{pH} \text { (SD) }\end{array}$} & \multicolumn{2}{|c|}{$\begin{array}{l}\text { Asthaxantine } \\
\text { ppm (SD) }\end{array}$} & \multirow[b]{2}{*}{ Anaest. } & \multirow{2}{*}{$\begin{array}{c}\text { Weight loss } \\
\% \text { (SD) }\end{array}$} \\
\hline & Anaest. & Crowded* & Anaest. & Crowded* & Anaest. & Crowded & & \\
\hline & $\begin{array}{l}28.00 \\
(0.63)\end{array}$ & $\begin{array}{r}27.00 \\
(6.39)\end{array}$ & $7.31(0.11)$ & $\begin{array}{cc}* & 6.39 \\
& (0.23)\end{array}$ & $\mathrm{Nd}$ & $\mathrm{Nd}$ & $\mathrm{Nd}$ & $\mathrm{Nd}$ \\
\hline 1 & $\begin{array}{l}26.00 \\
(0.42)\end{array}$ & $\begin{array}{r}25.00 \\
(0.76)\end{array}$ & $6.34(0.28)$ & $\begin{array}{cc}* \quad 5.98 \\
& (0.07)\end{array}$ & $6.97(1.44)$ & $6.98(2.08)$ & $\mathrm{Nd}$ & $\mathrm{Nd}$ \\
\hline 4 & $\begin{array}{l}25.00 \\
(0.57)\end{array}$ & $\begin{array}{l}25.00 \\
(0.50)\end{array}$ & $5.96(0.07)$ & $\begin{array}{c}5.87 \\
(0.08)\end{array}$ & $6.83(1.20)$ & $6.66(1.88)$ & $1.73(0.82)$ & * $2.72(0.95)$ \\
\hline 7 & $\begin{array}{l}25.00 \\
(0.42)\end{array}$ & $\begin{array}{l}25.00 \\
(0.46)\end{array}$ & $5.94(0.07)$ & $\begin{array}{c}5.99 \\
(0.10)\end{array}$ & $6.18(1.24)$ & $6.57(1.88)$ & $3.07(1.12)$ & * $4.35(1.07)$ \\
\hline 10 (Ref.) & $\begin{array}{l}25.00 \\
(0.48)\end{array}$ & $\begin{array}{l}25.00 \\
(0.46)\end{array}$ & $5.92(0.08)$ & $\begin{array}{c}5.72 \\
(0.86)\end{array}$ & $6.07(1.34)$ & 6.65 (1.76) & $5.10(1.10)$ & $5.59(1.37)$ \\
\hline
\end{tabular}

* different superscripts in the same line within a variable indicate statistical differences between treatment group $\mathrm{P}<0.05$ ).

* different superscripts in middle columns of the same variable indicate statistical differences between days post-mortem $(\mathrm{P}<0.05)$ in reference to 10 days post-mortem.

$\mathrm{Nd}=$ not determined.

Muscle $\mathrm{pH}$ was also significantly lower $(\mathrm{P}<0.05)$ in crowded fish until day 1 postmortem. There was no statistical difference $(\mathrm{P}>0.05)$ in asthaxantin content, neither between treatments, nor over time, postmortem. Weight loss was statistically greater $(\mathrm{P}<0.05)$ in crowded fish at days 4 and 7 postmortem. Within groups, the weight loss increased significantly $(\mathrm{P}<0.05)$ between days 4,7 and 10 .

\section{DISCUSSION}

This study was carried out to compare the effects of crowding and low oxygen on blood constituents and flesh quality parameters under controlled experimental conditions, but simulating those conditions used during harvest.

A primary response to stress is an increase in plasma cortisol levels (Barton and Iwama 1991, Barton 2002,
Acerete et al 2004), and it is widely used to index a stressful stimulus (Skjervold et al 1999). The $242.79 \mathrm{ng} /$ $\mathrm{ml}$ of cortisol obtained in the anaesthetized fish (table 1) was higher than the $100.4 \mathrm{ng} / \mathrm{ml}$ observed in previous work in low density and uncrowded Atlantic salmon (Skjervold et al 1999, Skjervold et al 2001). Other studies have found even lower values in the order of 20.9 $\mathrm{ng} / \mathrm{ml}$ for unstressed salmon (Erikson et al 1999). In our study there was no significant difference in cortisol concentration between anaesthetized and crowded fish. This could have been due to the fact that the cortisol level was already high, at over twofold the value found by others (Skjervold et al 2001). To accommodate the sampling protocol during this study, the daily schedule of handling and feeding of the fish was modified, which could have contributed to the elevated cortisol levels 
observed in the anaesthetized fish. These fish were sampled 30 minutes after the anaesthetic was poured in the water and not one hour after handling, as in the case of the crowded fish.

Osmotic changes during stress are affected directly by changes in branchial permeability to water and electrolytes (Redding and Schreck 1983). Changes seen in the levels of blood $\mathrm{Na}^{+}, \mathrm{Cl}^{-}$and osmolality in the crowded fish were consistent with this mechanism and the high levels of cortisol found in this study.

In the present work, after crowding, the blood monovalent ion $\mathrm{Cl}^{-}$increased over $10 \%$ (table 1). In previous studies (Iversen et al 1998) it has also been observed to increase in seawater adapted fish in response to handling or confinement. Additionally, a difference increase of $7 \%$ was observed in $\mathrm{Na}^{+}$concentration after crowding. This can be explained by the net transepithelial fluxes of $\mathrm{Na}^{+}$and $\mathrm{Cl}^{-}$in these euryhaline fish during stress (Redding and Schreck 1983). A major driver of these ionic imbalances is increased gill permeability, which in turn promotes the exchange rate of $\mathrm{Na}^{+}$and $\mathrm{Cl}^{-}$and water along concentration gradients (Urbinati et al 2004).

A short-term intensive stress generally leads to a large increase in cortisol concentration followed, after a set delay, by a concomitant change in glucose (Svobodová et al 1999). The mobilization of glucose in response to stress is generally accepted as being a means of providing extra energy resources, enabling the animal to overcome the disturbance (Acerete et al 2004), making increase of the glucose plasmatic concentration one of the most common indicators of the metabolic changes following stress (Iwama 1998, Reddy and Leatherland 1998). In this study, plasma glucose levels (table 1) in the anesthetized fish were within the range observed previously for harvest size Salmo salar (Erikson et al 1999, Skjervold et al 2001). Glucose concentration was increased by $76 \%$ in the crowded group. This is similar to values found in a previous study (Skjervold et al 2001) where an increase of $70 \%$ was seen in crowded fish.

With increased physical activity, pre-mortem, the greater is the depletion of glycogen and the formation of lactic acid (Roth et al 2002). Lactate concentration has been shown to increase significantly in several species following severe exercise or as a result of hypoxia (Acerete et al 2004). In our study, blood lactate in the crowded fish increased by over $300 \%$, significantly higher than in anesthetized fish (table 1), and indicative of a high level of anaerobic muscle activity (Thomas et al 1999). Skjervold et al (2001) showed similar results when comparing lactate levels in crowded and uncrowded Atlantic salmon. Fish white muscle mainly generates energy by means of anaerobic metabolism which results in an accumulation of lactic acid that must be transported to the liver for metabolization (Huss 1995). Our results for lactate agree with those of Thomas et al (1999), who found a significant increase in plasma lactate in two species of salmonids following lowering the water level, to simulate handling during harvest and forced exercise.

High stocking densities can be very stressful for fish (Erikson et al 1997'a Thomas et al 1999, Skjervold et al 2001, Bahuaud et al 2010). At slaughter, the cessation of blood circulation results in a decrease in oxygen concentration in the cell and a progressive reduction of the redox potential, leading to anaerobiosis (Toldrá 2003) and a reduction in muscle $\mathrm{pH}$, due to lactic acid accumulation (Einen and Thomassen 1998, Skjervold et al 2001). The more the fish struggle before and during harvesting and slaughtering procedures, the greater is the stress and the faster will be the post-mortem drop in muscle $\mathrm{pH}$ (Thomas et al 1999). The fall in post mortem muscle $\mathrm{pH}$ has an effect on the physical properties of the fillet, lowering the net charge of muscle proteins and causing a partial denaturation, which results in a diminished water holding capacity (Kristoffersen et al 2006). In our study, initial $\mathrm{pH}$ was significantly lower $(\mathrm{P}<0.05)$ in crowded than in anaesthetized fish (table 2). This is in accordance with a previous study where muscle $\mathrm{pH}$ was lower at slaughter in fish exposed to exercise, activity or stress before death (Gatica et al 2008, Bahuaud et al 2010). A lower initial $\mathrm{pH}$, post mortem, is associated with more rapid and detrimental quality changes in muscle properties (Huss 1995, Einen and Thomassen 1998, Skjervold et al 2001, Toldrá 2003). In the anaesthetized fish, initial pH was significantly higher (table 2) than in the crowded fish, probably indicative of a better quality, a longer pre rigor period, and therefore, also allowing a longer time to process the fish before rigor sets in. This is of great importance to the industry as a fish in rigor cannot be easily manually or mechanically processed: a rapid onset of rigor leaves a limited time in which to gut and process the fillets. There was no difference in $\mathrm{pH}$ between both treatments from the fourth day postmortem, as seen in table 2. In the case of the anaesthetized fish, the decrease in $\mathrm{pH}$ was faster than in the crowded fish. This is in agreement with (Robb 2001), who stated that there is no difference in final $\mathrm{pH}$ between stressed and unstressed fish of the same species in spite of presenting differences in initial post-mortem $\mathrm{pH}$ (Skjervold et al 2001, Bahuaud et al 2010).

As a consequence of $\mathrm{pH}$ drop, water binding decreases rapidly as the charge on proteins moves towards neutrality, causing a loss of water from the flesh (Toldrá 2003). In our study, one hour after death, both muscle $\mathrm{pH}$ and colour were significantly lower $(\mathrm{P}<0.05)$ in those fish subjected to crowding (table 1). This is in accordance with our previous work (Gatica et al 2008) in which fish subjected to the stress of transport had lower initial muscle $\mathrm{pH}$. These findings are supported by other authors (Robb et al 2000; Robb 2001), who stated that with a more rapid decrease in $\mathrm{pH}$, generally observed in fish which show higher muscle activity prior to slaughter, there are also significant changes in the colour of the salmon fillets. These same authors affirmed to that these changes in colour are a result of changes in the reflection of light from the surface of the fillet, due to the 
water loss from the flesh. As in this study it was possible to observe differences in colour between anaesthetized and crowded fish but there was no significant difference in the content of asthaxantin between both groups. This result suggests that the difference in colour is likely to be due to water loss due to protein denaturation, and this water loss also the cause of the significantly higher weight loss on days 4 and 7, post-mortem, in the fillets from the crowded fish (table 2). This change in colour, without a loss in pigment (asthaxantin) content, is very similar to an effect that occurs in pigs that are acutely stressed at slaughter, which results in paler flesh known as pale, soft and exudative (PSE) (Robb 2001).

It can be concluded that crowding increases blood concentrations of glucose, lactate, $\mathrm{Na}, \mathrm{Cl}$ and osmolarity. Effects were also seen within the muscle, where $\mathrm{pH}$ was lowered compared with anaesthetized fish until day four, postmortem. Low muscle $\mathrm{pH}$ lowers the water holding capacity of the proteins. This resulted in a greater weight loss in fillets from the crowded fish. The difference in colour observed between the crowded and anaesthetized fillets during the first two days, could not be attributed to a decrease in the content of the pigment asthaxantin under the conditions of this study but rather to a change in the relectance of the surface of the fillet of the crowded fish, due to greater loss of water content.

\section{SUMMARY}

The effects of anaesthesia (as a control treatment) and controlled crowding, with its concomitant low oxygen level, on harvest size salmon (Salmo salar) were compared in terms of blood constituents and flesh quality variables, at $0,1,4,7$ and 10 days post-mortem. Fish were held in tanks in triplicate and were sampled after anaesthetizing with AQUI$S \circledR$ and after crowding for one hour. Eighteen fish from each treatment were stunned, blood sampled from the posterior aorta and the fish bled by gill cut and filleted. All blood variables with the exception of cortisol were higher $(\mathrm{P}<0.05)$ in crowded fish compared with anaesthetized fish. Initial muscle $\mathrm{pH}$ was lower in the crowded fish and only between days $0 ; 1$ and 4 . Colour was significantly lighter in crowded than in anaesthetized fish on days 0 and 1 . Weight loss was higher $(\mathrm{P}<0.05)$ in the crowded fish and also increased in both treatments with time post mortem. Muscle asthaxantin concentration showed no statistical difference between treatments nor post mortem. It can be concluded that crowding and reduced oxygen level had a negative effect on blood variables and on flesh quality, lowering colour score, lowering initial muscle $\mathrm{pH}$, and increasing the weight loss of fillets.

\section{ACKNOWLEDGMENTS}

We are most grateful to DSM Nutritional Products Chile S.A., EWOS Innovation Chile S.A. and Universidad Austral de Chile, through its Project MECESUP AUS 0005, who financially supported this work. Also, we would like to thank Fundación Chile at Quillaipe Experimental Centre who provided facilities for the experiment.

\section{REFERENCES}

Acerete L, JC Balasch, E Espinosa, A Josa, L Tort. 2004. Physiological responses in Eurasian perch (Perca fluviatilis, L.) subjected to stress by transport and handling. Aquaculture 237, 167-178.
Barton BA, GK Iwama. 1991. Physiological changes in fish from stress in aquaculture with emphasis on the response and effects of corticosteroids. An Rev Fish Dis 1, 3-26.

Barton BA. 2000. Salmonid fishes differ in their cortisol and glucose responses to handling and transport stress. NAm J Aquic 62, 12-18.

Barton BA. 2002. Stress in fishes: a diversity of responses with particular reference to changes in circulating corticosteroids. Integ and Comp Biol 42, 517-525.

Bahuaud D, T Mørkøre, TK Østbye, E Veiseth-Kent, MS Thomassen, R Ofstad. 2010. Muscle structure responses and lysosomal cathepsins $\mathrm{B}$ and $\mathrm{L}$ in farmed Atlantic salmon (Salmo salar L.) pre- and postrigor fillets exposed to short and long-term crowding stress. Food Chemistry 118, 602-615.

Bell A, J Bron, JF Turnbull, CE Adams, FA Huntingford. 2002. Factors influencing the welfare of farmed Atlantic salmon (Salmo salar) in commercial marine cages. Res Vet Sci 72 (Suplement A), 7-8.

Einen O, MS Thomassen. 1998. Starvation prior to slaughter in Atlantic salmon (Salmo salar) II. White muscle composition and evaluation of freshness, texture and colour characteristics in raw and cooked fillets. Aquaculture 169, 37-53.

Erikson U, AR Beyer, T Sigholt. 1997ª . Muscle high-energy phosphates and stress affect K-values during ice storage of Atlantic salmon (Salmo salar). J Food Sci 62, 43-47.

Erikson U, T Sigholt, A Seland. $1997^{\mathrm{b}}$. Handling stress and water quality during live transportation and slaughter of Atlantic salmon (Salmo salar). Aquaculture 149, 243-252.

Erikson U, T Sigholt, T Rustad, IE Einarsdottir, L Jørgensen. 1999. Contribution of bleeding to total handling stress during slaughter of Atlantic salmon (Salmo salar). Aquic Inter 7, 101-115.

Foucat L, R. Taylor, GR Labas, JP Renou. 2004. Soft Flesh Problem in Freshwater Rainbow Trout Investigated by Magnetic Resonance Imaging and Histology. J Food Sci 69, 320-327.

Gatica MC, G Monti, C Gallo, TG Knowles, PD Warriss. 2008. Effects of Well-Boat Transportation, on Muscle $\mathrm{pH}$ and Onset of Rigor Mortis of Atlantic Salmon. Vet Rec 163, 111-116.

Håstein T. 2004. Animal welfare issues relating to aquaculture, OIE Global Conference on Animal Welfare, Paris, France, Pp 219-227.

Huss HH. 1995. Quality and quality changes in fresh fish. Food and Agriculture Organization of the United Nations. FAO Technical Paper, Rome, Italy, Pp 348.

Iversen M, B Finstad, KJ Nilssen. 1998. Recovery from loading and transport stress in Atlantic salmon (Salmo salar L.) smolts. Aquaculture 168, 387-394.

Iwama GK. 1998. Stress in Fish. Ann N Y Acad Sci 851, 304-310.

Iwama GK, LOB Afonso. A Todgham. P Ackerman. K Nakanao. 2004. Are hsps suitable for indicating stressed states in fish?, Commentary. J Exp Biol 207, 15-19.

Jittinandana S, PB Kenney, PM Mazik, M Danley, CD Nelson, RA Kiser, JA Hankins. 2005. Transport and stunning affect quality of artic char fillets. J Muscle Foods 16, 274-288.

Kestin S. 1994. Pain and stress in fish. In: RSPCA (Royal Society for the Prevention of Cruelty to Animals). Pp 36.

Kestin S, S Wotton, S Adams. 1995. The effect of $\mathrm{CO}_{2}$, concussion of electrical stunning of rainbow trout (Oncorhynchus mykiss) on fish welfare. In: European Aquaculture Society (eds) Quality in Aquaculture. Special Publication 23. Gent, Belgium, Pp 380-381

Kristoffersen S, T Tobiassen, V Steinsund, RL Olsen. 2006. Slaughter stress, postmortem muscle $\mathrm{pH}$ and rigor development in farmed Atlantic cod (Gadus morhua L.). Int J Food Sci Technol 41, 861-864.

Little RC, GA Milliken, WW Stroup, RD Wolfinger. 1996. SAS System for Mixed Models. Statistical Analysis System Institute, Cary, NC, USA.

Pottinger TG. 2001. Effects of husbandry stress on flesh quality indicators in fish. In: Kestin S, Warriss PD (eds). Farmed fish quality. Blackwell Science, Bristol, England, Pp 145-160.

Redding JM, CB Schreck. 1983. Influence of ambient salinity on osmoregulation and cortisol concentration in yearling coho salmon during stress. Trans Am Fish Soc 112, 800-807. 
Reddy PK, JF Leatherland. 1998. Stress Physiology. In: Leatherland JF, Woo PTK (eds). Fish diseases and disorders. Vol. 2. CABI Publishing, Oxford, UK, Pp 279-301.

Robb DHF. 2001. The Relationship between killing methods and quality. In: Kestin S, Warriss PD (eds). Farmed Fish Quality. Blackwell Science, Bristol, England, Pp 220-233.

Robb DHF, SC Kestin, PD Warriss. 2000. Muscle activity at slaughter: I. Changes in flesh colour and gaping in rainbow trout. Aquaculture 182, 261-269.

Robb DHF. 2003. How Harvest can Affect Quality, Canadian Edition, Surrey, EWOS Pp 9-12.

Roth B, D Moeller, JO Veland, A Imsland, E Slinde. 2002. The Effect of Stunning Methods on Rigor Mortis and Texture Properties of Atlantic salmon (Salmo salar). J Food Sci 67, 1462-1466.

Rottmann RW, R Francis-Floyd, R Durborow. 1992. The Role of Stress in Fish Disease in Southern Regional Aquaculture Center (SRAC), Publication $\mathrm{N}^{\circ} 474$.

Ruiz I, AB Fernández, IDe Blas. 2003. El sistema inmune de los teleósteos (IV): Principales factores que afectan a la respuesta inmune. AquaTIC 19, 1-7.

Singer, J. 1998. Using SAS PROC MIXED to fit multilevel models, hierarchical models and individual growth models. J Educ behav stat 24, 323-355.

Singer JD, JB Willett. 2003. Applied longitudinal data analysis: modeling change and event occurrence. Oxford University Press, New York, USA
Skjervold PO, SO Fjæra, PB Østby. 1999. Rigor in Atlantic salmon as affected by crowding stress prior to chilling before slaughter. Aquaculture 175, 93-101.

Skjervold PO, SO Fjæra, PB Østby, O Einen. 2001. Live-chilling and crowding stress before slaughter of Atlantic salmon (Salmo salar). Aquaculture 192, 265-280.

Svobodová Z, P Kaláb, L Dušek, B Vykusová, J Kolárová, D Janoušková 1999. The Effect of Handling and Transport on the Concentration of Glucose and Cortisol in Blood Plasma of Common Carp. Acta Veterinaria Brunensis 68, 265-274.

Thomas PM, NW Pankhurst, HA Bremner. 1999. The effect of stress and exercise on post-mortem biochemistry of Atlantic salmon and rainbow trout. J Fish Biol 54, 1177-1196.

Toldrá F. 2003. Muscle Foods: Water, Structure and Functionality. Food Sci Technol Inter 9, 173-177.

Urbinati EC, JS De Abreu, AC Da Silva Camargo, MA Landinez Parra. 2004. Loading and transport stress of juvenile matrinxa (Brycon cephalus, Characidae) at various densities. Aquaculture 229, 389-400.

Wall AJ 2001. Ethical considerations in the handling and slaughter of farmed fish. In: Kestin S, Warriss PD (eds). Farmed fish quality. Blackwell Science. Bristol, England, Pp 108-119.

Wendelaar Bonga SE. 1997. The stress response in fish. Physiol Rev 77, 1-39. 